\title{
Negative Pressure Pulmonary Edema: A Case Report
}

\author{
Anisha Budhathoki, ${ }^{1}$ Yawen Wu' \\ 'Department of Anesthesiology, Third affiliated Hospital of Guangzhou Medical University, Guangzhou, Guangdong, \\ China.
}

\section{ABSTRACT}

Negative pressure pulmonary edema is an uncommon complication of the extubation of the endotracheal tube. An increase in intrathoracic pressure and negative pressure of the lung caused by acute laryngeal spasm results from acute upper respiratory obstruction causing life-threatening pulmonary edema by alveolar-capillary damage is called negative pressure pulmonary edema. We here describe 28-years old female case the preoperative diagnosis of pelvic inflammatory disease undergoing exploratory laporoscopy caused negative pressure pulmonary edema while extubation. With the immediate treatment, the patient was discharged without any abnormalities.

Keywords: extubation; laryngospasm; pulmonary edema.

\section{INTRODUCTION}

Negative pressure pulmonary edema (NPPE) is noncardiogenic pulmonary edema, induce due to an increase in intrathoracic pressure and negative pressure of the lung as a result of acute laryngeal spasm during extubation. NPPE is a life-threatening condition during the extubation after general anesthesia. The prevalence of NPPE occurs in $0.05 \%$ to $0.1 \% .{ }^{1}$ It usually occurs in young healthy patients and during extubation due to which it is also called "post-extubation pulmonary edema." 2 We here discuss a case of 28 years old female case with a preoperative diagnosis of pelvic inflammatory disease occurring NPPE during extubation.

\section{CASE REPORT}

A 28-years old lady presented to the third affiliated hospital of Guangzhou Medical University with complaints of severe abdominal pain in the lower abdomen and pelvic, fever, and pain during intercourse for 3 months. Normal past medical history without any comorbidity. There was no history of any past surgery, trauma, allergies, smoking, drug addiction, and infectious diseases. No specific family history was found.

On physical examination, there was tenderness in lower abdominal parts and pale skin. All the other preoperative assessments including laboratory examinations, imaging examinations, and physical examinations were under normal range.

She was scheduled for exploratory laparoscopy surgery with general anesthesia. The patient was fasted for 12 hours. American society of anesthesiologists (ASA) of degree I with height $155 \mathrm{~cm}$, weight $70 \mathrm{~kg}$ was reported. Her Mallampati grade was II degree. Preoperative vital signs were stable with blood pressure of $110 / 60 \mathrm{mmHg}$, heart rate $60 / \mathrm{m}$, and $\mathrm{SpO}_{2} 100 \%$.

For Anesthesia induction drugs used sufentanyl 20 $\mu \mathrm{g}$, propofol $120 \mathrm{mg}$, rocurium $50 \mathrm{mg}$, perecoxib 40 $\mathrm{mg}$, remifentanyl $0.1 \mu \mathrm{g} / \mathrm{kg} / \mathrm{min}$ continuous infusion, and desflurance $5 \%$ continuous infusion. Operation start time 8:45 am. Her vital signs during the operation were stable. $\mathrm{EtCO}_{2}$ was under normal range. The minimum alveolar concentration (MAC) was 6 to 6.2 . Intraabdominal carbondioxide pressure was less than

Correspondence: Dr. Anisha Budhathoki, Department of Anesthesiology, Third affiliated Hospital of Guangzhou Medical University, Duobao, Guangzhou, Guangdong, China. Email: musicanisha@yahoo.com, Phone: +8615625178217. 
$15 \mathrm{mmHg}$. Rocurium $10 \mathrm{mg}$ was given with 40 mins interval. Total operation duration was 2 hours. A total of $1500 \mathrm{~mL}$ of ringer lactate solution was administered during the surgery, the urine output was approximately $200 \mathrm{~mL}$, and blood loss was less than $20 \mathrm{~mL}$.

Extubation was done at 11:00 am with self spontaneous breathing observation, tidal volume of $400 \mathrm{~L}$, and when she obeyed the command of opening eyes. Right after extubation patient had breathing difficulties, with mask ventilation positive pressure $\mathrm{SpO}_{2}$ was $88 \%$. But it was ineffective, the further deterioration of $\mathrm{SpO}_{2}$ was observed with $75 \%$ to $60 \%$. Pink frothy sputum was found around the mouth and during suction. Atropine 0.5 $\mathrm{mg}$, neostigmine $1 \mathrm{mg}$ was given. Bilateral pulmonary rales were auscultated at the time. With failure to raise in $\mathrm{SpO}_{2}$ patient was reintubated at 11:17 am with sevoflurance $1.8 \%$ continuous inhalation, fursemide $20 \mathrm{mg}$, methyprednisolone $80 \mathrm{mg}$, aminophyline 0.125 $\mathrm{mg}$, dexmedetomide $20 \mu \mathrm{g}$, and ephidrine $6 \mathrm{mg}$ was given. The $\mathrm{SpO}_{2}$ gradually returned to normal and the patient was taken to the Post-operative care unit (PACU) with an endotracheal tube. In PACU physical warmer, cis-atracurium $5 \mathrm{mg}$ was used with continuous observation. The blood gas analysis and chest X-ray was taken immediately. The vital signs and urine output was normal in PACU. After 4 hours of observation, the patient was extubated successfully. The patient was sent to the ward without any discomfort and abnormalities.

A chest X-ray is taken when the patient was sent to PACU and after 4 hours (Figure 1). The chest X-ray at the left side taken when the patient was sent to PACU showed bilateral diffuse, bilateral, hazy, interstitial opacity, pulmonary infiltration throughout both lungs. The chest $X$-ray at the right side taken after 4 hours patient was sent to PACU showed resolution of the process.

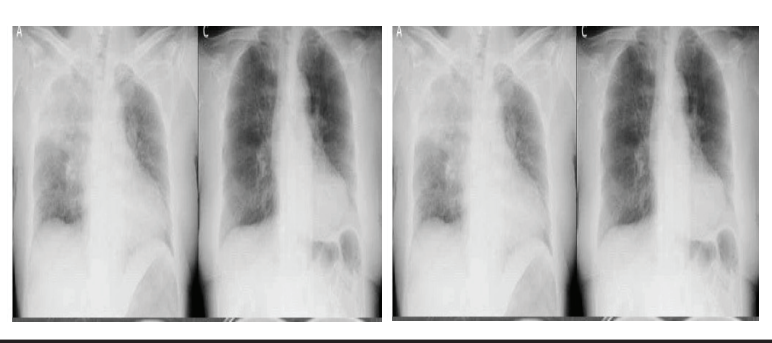

Figure 1. X-ray taken after reintubation and after 4 hours.

ABG at left side taken when the patient was sent to PACU and right side was taken after 4 hours showed improved $\mathrm{SpO}_{2}$ (Table 1).

\begin{tabular}{|c|c|c|}
\hline \multicolumn{2}{|c|}{$\begin{array}{l}\text { Table } 1 . A B C \text { taken after reintubation } \\
\text { and after } 4 \text { hours. }\end{array}$} & \multirow[b]{2}{*}{$\begin{array}{l}\text { ABG after } 4 \\
\text { hours }\end{array}$} \\
\hline Parameters & $A B G$ at PACU & \\
\hline Base excess (BE) & $1.0 \mathrm{mmol} / \mathrm{L}$ & $1.0 \mathrm{mmol} / \mathrm{L}$ \\
\hline Calcium (Ca) & $1.10 \mathrm{mmol} / \mathrm{L}$ & $1.10 \mathrm{mmol} / \mathrm{L}$ \\
\hline Chlorine (CI) & $101 \mathrm{mEq} / \mathrm{L}$ & $102 \mathrm{mEq} / \mathrm{L}$ \\
\hline Glucose (Glu) & $7.3 \mathrm{mmol} / \mathrm{L}$ & $7 \mathrm{mmol} / \mathrm{L}$ \\
\hline Haemoglobin $(\mathrm{Hb})$ & $123 \mathrm{~g} / \mathrm{dl}$ & $120 \mathrm{~g} / \mathrm{dl}$ \\
\hline Bicarbonate $\left(\mathrm{Hco}_{3)}\right.$ & $24 \mathrm{mEq} / \mathrm{L}$ & $23.3 \mathrm{mEq} / \mathrm{L}$ \\
\hline Haematocrit (Hct) & $36 \%$ & $37 \%$ \\
\hline Potassium (K) & $3.86 \mathrm{mEq} / \mathrm{L}$ & $3.96 \mathrm{mEq} / \mathrm{L}$ \\
\hline Sodium $\left(\mathrm{Na}^{+}\right)$ & $140 \mathrm{mEq} / \mathrm{L}$ & $143 \mathrm{mEq} / \mathrm{L}$ \\
\hline $\begin{array}{l}\text { Partial pressure of } \\
\text { carbondioxide }\left(\mathrm{PaCO}_{2}\right)\end{array}$ & $44 \mathrm{mmHg}$ & $42 \mathrm{mmHg}$ \\
\hline Acidity (pH) & 7.32 & 7.35 \\
\hline $\begin{array}{l}\text { Partial pressure of } \\
\text { oxygen }\left(\mathrm{PaO}_{2)}\right.\end{array}$ & $60 \mathrm{mmHg}$ & $100 \mathrm{mmHg}$ \\
\hline $\begin{array}{l}\text { Oxygen saturation } \\
\left(\mathrm{SpO}_{2}\right.\end{array}$ & $70 \%$ & $97.6 \%$ \\
\hline
\end{tabular}

After the patient was sent to ward $A B G$ report was found under normal ranges, timely vitals, and urine output observation was done. The blood gas analysis (ABG) and chest $\mathrm{X}$-ray was taken regularly with no suspicion and abnormalities. Then the patient was discharged without any abnormalities after 3 days.

\section{DISCUSSION}

Negative pressure pulmonary edema is an uncommon complication of the extubation of the endotracheal tube. NPPE has been reported mainly by anesthetists as a consequence of postoperative laryngospasm. ${ }^{3}$ The pathophysiology of NPPE begins with acute laryngeal spasm leading to severe upper airway obstruction. Intrathoracic pressure during acute upper airway obstruction is ( $>-100 \mathrm{~cm} \mathrm{H}_{2} \mathrm{O}$ ) whereas normal inspiratory chest pressure is $\left(-2\right.$ to $\left.-5 \mathrm{~cm} \mathrm{H}_{2} \mathrm{O}\right)$. The absolute value of intrathoracic transpulmonary negative pressure leads to the reduce of alveolar-capillary membrane pressure causing disruption of capillary barrier and alveolar epithelial barrier. All these causes exudation of blood vessels, which makes the red blood cells leak into the alveoli and causes significant lung or bronchial bleeding. These changes lead to red blood cell filtration into the lung and pulmonary edema. ${ }^{4}$ The increase in pulmonary blood volume occurs due to the increase in systemic arterial pressure secondary to the release of norepinephrine in response to hypoxia, hypercapnia, and agitation. Frothy pink pulmonary secretions is one of the most important syndrome to diagnose NPPE during extubation. And before making 
the diagnosis of NPPE, other causes of pulmonary edema particularly those requiring a rapid intervention (fluid maldistribution, anaphylaxis, and cardiogenic pulmonary edema), must be considered. ${ }^{5}$

The main diagnosis is done by incidence and symptoms, chest radiograph for pulmonary edema, and measure of pulmonary edema fluid/plasma protein ration. With proper treatment, NPPE can rapidly dissipate. The most important treatments include re-establishment of the airway by relief airway obstruction. Adequate oxygenation should be given, encourage the patient to cough after extubation. Application of positive airway pressure via face mask or LMA or Endotracheal intubation with ventilator support. Although NPPE does not result from fluid overload, it is recommended gentle diuresis using low-dose furosemide. ${ }^{6}$ The clinical syndromes can usually improves after 12-24 hours. $^{7}$ But in our case, the symptoms were improved within 4 hours without any abnormalities. Patients with NPPE history should be kept in mind and prevention methods can be performed accordingly. It is also believed that the incidence of EPPN is higher than that found in the literature due to the fact that the cases are poorly diagnosed and, in many cases, confused with pulmonary edema due to fluid overload, aspiration pneumonitis and bronchospasm. ${ }^{8}$

\section{ACKNOWLEDGMENTS}

We would like to thank Dr. Liu Jie for his valuable support and guidance.

Consent: JNMA Case Report Consent Form was signedby the patient and the original article is attached withthe patient's chart.

\section{Conflict of Interest: None.}

\section{REFERENCES}

1. Liu RZ, Wang J, Zhao GQ, Su ZB. Negative pressure pulmonary edema after general anesthesia: a case report and literature review. Medicine (Baltimore). 2019 Apr;98(17):e15389. [uuㄹ | Full Text | DOI]

2. Pathak V, Rendon IH, Ciubotaru RL. Recurrent negative pressure pulmonary edema. Clin Med Res. 2011 Jun;9(2):88-91. [ubMed | Full Text | DOI]

3. Bhaskar B, John JF. Negative pressure pulmonary edema revisited: pathophysiology and review of management. Saudi Journal of Anaesthesia. 2011 Jul-Sep;5(3):308-13. [Full Text $\mid \underline{\mathrm{DOI}}$

4. Lemyze M, Mallat J. Understanding negative pressure pulmonary edema. Intensive Care Medicine. 2014 May 6;40(8):1140-3. [Full Text | DOI]
5. Krodel DJ, Bittner EA, Abdulnour R, Brown R, Eikermann M. Case scenario: acute postoperative negative pressure pulmonary edema. Anesthesiology. 2010 Jul;113:200-7. [ull Text $\mid \underline{D O I}]$

6. Bhattacharya M, Kallet RH, Ware LB, Matthay MA. Negative-pressure pulmonary edema. Chest. 2016;150(4):927-33. [ㄹued | Full Text | DOI]

7. Xiong J, Sun YX. Negative pressure pulmonary edema: a case report. BMC Anesthesiol. 2019 May 1;19:63. [PubMed | Full $\underline{\text { Text }}$ | DOI]

8. Albergaria VF, Soares CM, Araujo RDM, Mendonca WLD. Negative- pressure pulmonary edema after transsphenoidal hypophysectomy. Case Report. Rev Bras Anesthesiol. 2008 Jul-Aug;58(4):391-6. [PubMed | Full Text | DOI] 